\title{
Pelaksanaan Program Dakwah dan Pemberdayaan Santri Pondok Pesantren Hataska Semurup Kerinci-Jambi
}

\author{
Dedi Iria Putra \\ Universitas Islam Negeri Imam Bonjol Padang \\ dediiriaputra@gmail.com
}

\begin{abstract}
Pondok Pesantren as an educational institution that develop spiritual and life skills. One of them Pondok Pesantren Hataska. The problem in this research is what is the program of empowering students of Pondok Pesantren Hataska Semurup Kerinci-Jambi. How the implementation of empowerment program students of boarding school Hataska Semurup Kerinci-Jambi regency. There are five basic concepts of da'wah and the development of Islamic society 1. Ukhuwah (the importance of unity to gain strength) 2. Ta'awun (the inter-team approach in community development) 3. 'Amilun (a group with enough skills) 4. Ma'rifah (cultural understanding of society) 5. Yaqin have the ability to be independent). Pesantren is an institution that combines formal and non formal education that prioritizes the practice of Islamic values that become the daily lifestyle, with the development of pesantren also preparing santri in the field of life skill so as to adapt well when returning to society. In the implementation of empowerment program students of Hataska Pondok Pesantren in the field of spiritual and life skill implemented three stages: first, the giving of material. Second, training. Third, the implementation.
\end{abstract}

Keywords, Dakwah, Empowerment of Students, Pondok Pesantren

Abstrak
Pondok Pesantren sebagai institusi pendidikan yang
mengembangkan ketrampilan spiritual dan kehidupan. Salah satunya
Pondok Pesantren Hataska. Permasalahan dalam penelitian ini
adalah bagaimana program pemberdayaan siswa Pondok Pesantren
Hataska Semurup Kerinci-Jambi. Bagaimana pelaksanaan program
pemberdayaan siswa pesantren Hataska Semurup Kabupaten
Kerinci-Jambi. Ada lima konsep dasar dakwah dan perkembangan
masyarakat Islam 1. Ukhuwah (pentingnya kesatuan untuk
mendapatkan kekuatan) 2. Ta'awun (pendekatan antar tim dalam
pengembangan masyarakat) 3. 'Amilun (sebuah kelompok dengan


cukup keterampilan) 4. Ma'rifah (pemahaman budaya masyarakat) 5 . Yaqin memiliki kemampuan untuk mandiri). Pesantren adalah institusi yang menggabungkan pendidikan formal dan nonformal yang mengutamakan praktik nilai-nilai Islam yang menjadi gaya hidup sehari-hari, dengan perkembangan pesantren juga mempersiapkan santri di bidang kecakapan hidup agar dapat beradaptasi dengan baik saat kembali ke masyarakat. Dalam pelaksanaan program pemberdayaan siswa Pondok Pesantren Hataska di bidang spiritual dan life skill dilaksanakan tiga tahap: pertama, pemberian materi. Kedua, pelatihan. Ketiga, implementasinya.

Kata kunci, Dakwah, Pemberdayaan Santri, Pondok Pesantren

\section{Pendahuluan}

Pondok pesantren merupakan lembaga pendidikan yang sudah berdiri sebelum penjajahan datang ke Indonesia. Pondok pesantren merupakan lembaga pendidikan Islam yang di dalamnya diajarkan dan diberikan ilmu-ilmu agama kepada santri yang tinggal di lingkungan psantren tersebut. ${ }^{1}$

Secara bahasa pondok pesantren terdiri dari dua kata, yaitu pondok dan pesantren. Pondok berasal dari bahasa Arab yaitu funduq yang berarti hotel atau asrama. Sedangkan pesantren berasal dari kata santri, yang dengan awal pe di depan dan akhiran an yang berarti tempat belajar santri. ${ }^{2}$ Jadi pondok pesantren adalah asrama tempat belajar santri. Sebagai lembaga pendidikan Islam tertua di Indonesia

Dalam hal penyelenggaraan sistem pendidikan dan pengajaran di pondok pesantren, paling tidak memiliki tiga bentuk, yaitu ${ }^{3}$ Pertama: Pesantren berbentuk sebagai lembaga pendidikan dan pengajaran agama Islam, diberikan dengan cara non-klasikal (sistem bandeng dan sorongan). Kedua: Pesantren berbentuk sebagai lembaga pendidikan dan pengajaran agama Islam para santrinya tidak disediakan pemondokan di komplek pesantren, namun tinggal tersebar di sekitar penjuru desa sekeliling pesantren tersebut (santri kalong) dimana metode pendidikan

1 Haidar Putra Daulay, Pendidikan Islam Dalam Sistem Pendidikan Nasional Di Indonesia (Jakarta: Kencana 2004) cet-1, 25

${ }^{2}$ Zamakhsyari Dhofier, Tradisi Pesantren: Studi Tentang Pandagan Kiyai (Jakarta: LP3S, 1998 (Cet. VII)), 18

${ }^{3}$ A. Mujib, et. al., Intelektualisme Pesantren: Potret Tokob dan Cakrawala Pemikiran di Era Perkembangan Pesantren (Cet. III; Jakarta: Diva Pustaka, 2006), 1. 
dan pengajaran agama Islam diberikan dengan sistem weton, yaitu para santri datang berduyun-duyun pada waktu tertentu untuk belajar bersama kiyai. Ketiga: pesantren berbentuk sebagai lembaga gabungan antara sistem Pondok dan Pesantren. Dalam hal ini, pondok pesantren memberikan pendidikan dan pengajaran agama Islam dengan sistem Bandongan, Sorongan, atau Wetona, ${ }^{4}$

Ada lima syarat pondok pesantren sehingga ia disebut sebagai lembaga pengembangan, serta yang membedakannya dengan lembagalembaga pendidikan yang lainnya yaitu: ${ }^{5}$ Pertama: pondok sebagai tempat tinggal kiyai dan ustadz/ ustadzah dan santri-santrinya untuk mempermudah proses belajar mengajar serta pengamalan ilmu yang sudah dipelajari. Kedua: masjid, merupakan tempat melaksanakan sholat berjamaah setiap lima waktu. Ketiga: santri, ${ }^{6}$ merupakan unsur pokok dari suatu pesantren, santri biasanya terbagi kepada dua bagian, yaitu: 1) Santri Mukim, biasanya ialah santri yang berasal dari daerah jauh kemudian menetap dalam pondok pesantren, 2) Santri Kalong, ialah santri-santri yang berasal dari daerah-daerah sekitar pesantren dan biasanya tidak menetap dalam pesantren. ${ }^{7}$ Keempat: adanya kiyai dalam pesantren merupakan hal yang mutlak bagi sebuah pesantren, sebab dia adalah tokoh sentral yang memberikan pengajaran, karena kiyai merupakan salah satu unsur yang paling dominan dalam kehidupan suatu pesantren. ${ }^{8}$ Kelima: $\quad$ kitab-kitab Islam klasik, ini merupakan unsur pokok yang paling membedakan pesantren dengan lembaga pendidikan lainnya.

Upaya pemberdayaan santri pondok pesantren melalui kegiatankegiatan life skill (keterampilan hidup), dan kegiatan pemberdayaan lainnya serta pengamalan keagamaan secara langsung bagai santri disuatu pondok pesantren untuk menuju santri yang berkualitas diperlukan

${ }^{4}$ Departemen Agama Repoblik Indonesia, Pedoman Pembinaan Pondok Pesantren, (Jakarta; Ditjen Bimbingan Islam, 1985), 9-10

${ }^{5}$ Manfred Ziemek, Pesantren Dalam Perubahan Sosial (Cet. I; Jakarta: P3M, 1986), 9899.

${ }^{6}$ Asal-usul kata santri, terdapat dua pendapat. Pertama, santri berasal dari perkataan "sastri", yang berasal dari bahasa Sankskerta, artinya melek buruf. Kedua, santri berasal dari bahasa jawa, persisnya dari kata "cantrik,", yang artinya seseorang yang selalu mengikuti seseorang guru kemana guru itu pergi menetap, agar si santri dapat menimba ilmu dari si Guru tersebut tentang suatu keahlian. Lebih jelasnya lihat Nurcholish Madjid, Bilik-Bilik Pesantren Sebuab Potret Perjalanan, (Jakarta: Paramadina, 2007), 19-20.

${ }^{7}$ Lihat juga Badrus Shaleh, Budaya Damai Komunitas Pesantren, (Jakarta: Lembaga Studi Agama dan Filsafat bekerjasama dengan The Asia Foundation, 2007), h. 11

${ }^{8}$ Biasanya kiyai didalam pesantren itu adalah pendiri sekaligus pengasuh pondok pesantren yang senantiasa menjaga nilai-nilai agama, lebih jelasnya lihat Mastuhu, op.cit., 126 
penerapan program pemberdayaan yang matang, sehingga out put dari pondok pesantren dapat diandalkan.

Berangkat dari kepedulian tentang pentingnya pemberdayaan santri melalui program-program yang diharapkan, maka Pondok Pesantren Hataska sebagai lembaga pendidikan Islam mencoba untuk mengembangkan suatu strategi dalam pelaksanaan pemberdayaan terhadap santrinya seperti pemberdayaan life skill (keteramplan hidup) pengenalan dan pengembangan terhadap ilmu Teknologi Informasi dan Komunikasi (TIK), Teknik Sepeda Motor (TSM), kepramukaan, seni bela diri, belajar bahasa Arab dan bahasa Inggris, khaligrafi dan pemberdayaan spiritual seperti belajar fiqih ibadah, dakwah, rebana, nasyid, seni baca Alquran, serta melaksanakan sholat berjamaah, dalam rangka menciptakan siswa yang memiliki skil individu, intelektual yang berbudaya, berakhlak mulia, yang beriman dan bertanggung jawab terhadap dirinya, keluarga maupun masyarakat. dakwah bukan saja hanya menyampaikan ceramah, pengajian, wirid, kultum dan sebagainya, namun dakwah menyentuh semua aspek kehidupan manusia, kata makruf bersifat umum, maka pengembangan masyarakat adalah bagian dari kajian dakwah, mengajak, mendidik seseorang untuk bekerja dan memotivasi supaya giat bekerja dan tidak boleh malas, meningkatkan kualitas ekonomi, atau memberikan contoh kepada seseorang supaya dia bisa melakukan sesuatu sesuai dengan apa yang kita lakukan (dakwah hal bilisan).

\section{Landasan Teori Dan Kerangka Koneptual}

\section{Pondok Pesantren}

\section{a. Pengertian Pondok Pesantren}

Secara bahasa pondok pesantren terdiri dari dua suku kata, yaitu Pondok dan pesantren, pondok berasal dari bahasa Arab yaitu funduq yang berarti hotel atau asrama. Sedngkan pesantren berasal dari kata santri, yang dengan awalan pe dan depan akhiran an yang berarti tempat belajar para santri. ${ }^{9}$ A.H. Johns berpendapat bahwa istilah santri berasal dari bahasa Tamil, yang berarti guru mengaji. ${ }^{10}$ Adapun menurut C.C Breg berpendapat bahwa istilah santri berasal dari kata shastri yang dalam bahasa India berarti orang atau buku-buku agama

${ }^{9}$ Zamakhsyari Dhofier, Tradisi Pesantren: Studi Tentang Pandagan Kiyai (Cet. VII: Jakarta: LP3S, 1998), 18

${ }^{10}$ A.H. Johns, Rom Coastal Settlement To Islamic School And Citi: Islamization In In Sumatra, The Malay Paninsula And Java, Dalam J. Fox (ed), Indonesia: The Making of a Culture ( Camberra: RS. P.S., 1980), 40 
Hindu, atau seorang sarjana ahli kitab suci agama Hindu. Lebih lanjut beliau mengungkapkan bahwa kata shastri berasal dari bahasa shastra yang berarti buku-buku suci, buku-buku agama atau buku tentang ilmu pengetahun. ${ }^{11}$ Jadi secara singkat pondok pesantren dapat dipahami sebagai lembaga atau tempat belajar santri yang di dalamnya dipelajari ilmu-ilmu agama Islam secara mendalam serta pengamalannya dalam kehidupan sehari-hari

\section{b. Pondok Pesantren Sebagai Lembaga Pendidikan dan Lembaga Pemberdayaan}

Setiap orang mengenal bahwa Pondok Pesantren merupakan suatu lembaga pendidikan klasik yang mungkin paling tradisional di negeri ini. Akan tetapi, melalui kebanggaan tradisionalitasnya, tidak dipungkiri, pondok pesantren semakin prima, bahkan kadang dianggap sebagai alternatif di dalam glamouritas dan hegemoni modernisme yang dalam waktu bersamaan mengagendakan tradisi sebagai masalah. ${ }^{12}$

Maka niai-nilai tradisionalitas yang menjadi bagian penting dalam kehidupan pesantren merupakan kekayaan tersendiri yang menjadi landasan bergerak pesantren dalam setiap perjalanannya, karena dengan tradisionalitas itulah, pesantren mampu bertahan menjadi lembaga yang sangat fenomenal dalam konteks kehidupan bangsa Indonesia. Pesantren tidak hanya akan dibaca sebagai lembaga pendidikan keagamaan, tetapi juga acapkali menjadi permainan dalam setiap perubahan yang akan terjadi. Seperti pemberdayaan spiritual yang merupkan ciri khas utama sebagai pondok pesantren dan pemberdayaan life skill.

\section{c. Pondok Pesantren Sebagai Lembaga Pengembangan Masyarakat}

Lembaga pesantren yang otonom, besar dan bergerak karena faktor masyarakat bawah, harus tetap terjaga identitasnya dan secara terus menerus untuk dikembangkan, sehingga mampu menjadi lembaga yang betul-betul memberikan kontribusi yang sangat berarti bagi kehidupan bangsa dan negara. Karena dengan cara yang demikian, target untuk melahirkan genersi-generasi yang ber-IMTAQ dan ber-IPTEK,

\footnotetext{
${ }^{11}$ C.C. Big, "Indonesia" dalam H.A.R. Gibb (ed). Whiter Islam ; A Survey of Moderen Movement in The Moslem World (London; 1932), 257

${ }^{12}$ Marzuki wahied (dkk), Pesantren Masa Depan Wacana Pemberdayaan Dan Transpormasi Pesantren (Bandug: Pustaka Hidayah, 2000), 145-146
} 
akan dengan mudah dilahirkan khususnya oleh lembaga pendidikan yang bernama pondok pesantren.

\section{Konsep Dakwah dan Pemberdayaan Masyaraka Islam}

a. Pengertian Serta Prinsi-prinp Dakwah dan Pemberdayaan Masyaraka Islam

Pemberdayaan masyarakat diartikan sebagai suatu upaya untuk memberikan daya (empowerment). Pemberdayaan erat kaitannya dengan kekuasaan. Kekuasaan identik dengan kemampuan individu untuk membuat dirinya atau pihak lain melakukan apa yang diinginkan. Daya atau kekuasaan harus diberikan kepada kelompok maupun individu sebagai langkah awal untuk mengatur kehidupan mereka secara mandiri.

Konsep pemberdayaan sering dikaitkan dengan dakwah. Munurut Welhendri antara dakwah dan pemberdayaan memiliki keterikatan yang cukup signifikan bahkan secara terperinci dapat dikatakan bahwa dakwah adalah proses pemberdayaan masyarakat. Makna dakwah sebagai proses pemberdayaan tidak terlepas dari tiga dimensi dakwah, yaitu makro, mezo, dan mikro. Tingkatan makro berupa hidayah, muatannya murni berupa al-Qur'an dan Sunnah. Tingkatan mezo integral tingkatan makro sebagai hasil penelaahan dari kandungan al-qur'an dan sunnah berupa metodologi, yaitu konsep, teori, dan kebijakan. Adapun tingkatan mikro adalah aktualisasi berupa tindakan, kegiatan, dan sebagainya yang berupa kerja nyata. ${ }^{13}$

\section{b. Pemerintah Sebagai Pelaku Pemberdayaan}

Pemerintah sebagai pemegang kekuasaan disebuah wilayah bertanggung jawab untuk memajukan daerah yang dipimpinnya. Salah satu caranya melalui berbagai program pemberdayaan masyarakat.

Pemerintah sebagai pelaku pemberdayaan bisa berperan sebagai fasilitator. Secara garis besar peran fasilitator pemberdayaan masyarakat memiliki tiga peran, yaitu: Pertama: sebagai pembangkit kesadaran terhadap pentingnya perubahan. Kedua: sebagai motivator penggerak perubahan. Ketiga: sebagai mediator dengan berbagai pemangku kepentingan. ${ }^{14}$

13 Welhendri Azwar, Sosiologi Dakwah (Padang: Imam Bonjol Press. 2014), 151-152 ${ }^{14}$ Ibid., 178 
Pada saat ini peran sebagai fasilitator juga bertanggung jawab untuk menjembatani hubungan antara pemangku kekuasaan dengan berbagai komponen yang terkait dalam proses pemberdayaan. ${ }^{15}$ Selain itu Fasilitaor juga berperan sebagai pemberi penyadaran/ motivator, pendorong pembangunan, mengatur/ organizing, memfasilitasi atau memperlancar kelompok dan sebagainya. ${ }^{16}$

\section{c. Pelatihan Sebagai Proses Pemberdayaan}

Hal terpenting yang harus diketahui oleh pelaku pemberdayaan adalah pemberdayaan harus dimulai dengan menciptakan kondisi atau suasana yang mengarah kepada terciptanya kemandirian masyarakat sebagai tujuan dari pemberdayaan. Penjelasan tersebut dipertegas dengan pernyataan Setiana. ${ }^{17}$ Proses pelatihan bila ditinjau dari strategi pemberdayaan masyarakat merupakan proses pemberdayaan secara kolektif. Dalam pelatihan tidak ada dilakukan secara relasi satu lawan satu antara fasilitator dan masyarakat. Meskipun dalam beberapa situasi ada proses pemberdayaan masyarakat secara individual, tetapi pada akhirnya strategi ini berkaitan dengan kolektivitas. Pelaksanaan pelatihan seperti itu, merupakan bentuk strategi aras mez:o yaitu pemberdayaan dilakukan secara kolektif. Seperti yang dikemukakan Edi Suharto ${ }^{18}$

\section{d. Manajemen Pemberdayaan Masyarakat}

Keberdayaan masyarakat tidak sekedar menekankan pada hasil, tetapi juga pada proses melalui partisipasi yang tinggi, berbasis pada kebutuhan dan potensi masyarakat. Untuk meraih keberhasilan itu, dapat dilakukan pendekatan bottom up dengan cara menggali potensi dan kebutuhan masyarakat. Keterlibatan masyarakat dalam prosesnya membuat mereka memiliki ikatan emosional untuk mensukseskan program pemberdayaan. ${ }^{19}$

Gerakan masyarakat berbeda dengan membuat model atau percontohan. Suatu model cenderung harus membuat dulu model percontohan tertentu secara ideal, selanjutnya setelah diuji baru disebar luaskan. Berbeda dengan strategi gerakan masyarakat,

15 Totok Murdikanto, op.cit., 140.

16 Aziz Muslim, Metodologi Pengembangan Masyarakat (Yogyakarta: Teras, 2009), $72-73$.

${ }^{17}$ Setiana L, Teknik Penyuluban dan Pemberdayaan Masyarakat (Bogor: Bhalia Indonesia, 2005), 13

${ }^{18}$ Edi Suharto, op.cit., 66

${ }^{19}$ Oos M, op.cit., 87 
ditempuh melalui jangkauan masyarakat sebanyak-banyaknya dengan menggali sebanyak mungkin informasi dari mereka. Pada akhirnya masyarakat beradaptasi dan menyesuaikan. ${ }^{20}$

\section{e. Faktor Penghambat Pemberdayaan}

Beberapa faktor penyebab penghambat pemberdayaan antara lain adalah:
a. Perbedaan paradigma pemberdayaan
b. Strategi pemberdayaan yang kurang tepat
c. Penggunaan metode yang salah
d. Pemahaman budaya

\section{f. Pemberdayaan Pesantren}

a) Pemberdayaan Spiritual Santri

Keunikan pondok pesantren masih konsisten dengan menyuguhkan suatu sistem pendidikan yang mampu menjembatani kebutuhan fisik (jasmani) dan kebutuhan mental spiritual (rohani) manusia. ${ }^{21}$

Eksistensi pondok pesantren dalam menyikapi perkembangan zaman, tentunya memiliki komitmen untuk tetap menyuguhkan pola pendidikan yang mampu melahirkan sumber daya manusia yang handal. Para santri harus dibekali nilai-nilai keislaman yang dipadukan dengan keterampilan. Pembekalan ilmu dan keterampilan dapat ditempuh dengan mempelajari tradisi ilmu pengetahuan agama dan penggalian dari teknologi dan keterampilan umum. ${ }^{22}$

Setidaknya disebabkan Pertama, ${ }^{23}$ pesantren sebagai lembaga pendidikan pengkaderan ulama. Kedua, pesantren sebagai lembaga pengembangan ilmu pengetahuan khusus agama Islam. Ketiga, dunia pesantren harus mampu menempatkan dirinya sebagai transformasi, motivator, dan inovator.

\footnotetext{
${ }^{20}$ Suyono, Pedoman Pelaksanan KKN Pos Pemberdayaan Keluarga (Posdaya) (Jakarta: Citra Kharisma Bunda, 2009), 39

${ }^{21}$ A. Mujid, et, al,. Intelektualisme Pesantren: Potret Tokoh dan Cakrawala Pemikiran di Era Perkembangan Pesantren, (Jakarta: Diva Pustaka, 2006), Cet. Ke-3, 1

22 Amin Haedari, et al., Masa depan Pesantren Dalam Tantangan Modernitas dan Komplesitas Global (Jakarta: IRD Perss, 2004), 3

${ }^{23}$ Abdullah Aly, Pendidikan Multikultural di Pesantren Telaab Terbadap Kurikulm

Pesntren Moderen Islam Asslalam Surakarta (Yogyakarta: Pustaka Pelajar, 2011). Cet. Ke.1, 154156
} 
b) Pemberdayaan Life Skill (keterampilan hidup)

Life skill adalah upaya membantu peserta didik atau santri untuk mengembangkan kemampuan berpikir, menghilangkan kebiasaan yang kurang tepat, dan mengembangkan potensi diri agar dapat memecahkan problem kehidupan secara konstruktif, inovatif dan kreatif sehingga dapat mengahadapi realita kehidupan dengan baik secara lahiriah maupun secara batiniah. ${ }^{24}$

Pengembangan life skill dalam konteks globalisasi serta dengan kompetensi dimana pemenangnya sangat ditentukan oleh kualitas sumberdaya manusia. Bagi bangsa Indonesia siap atau tidak harus siap masuk didalamnya. Persiapan sumberdaya manusia merupakan kunci utama untuk memetik kemenangan dalam persaingan globalisasi. Hanya saja persiapan bangsa Indonesia kearah itu mungkin belum begitu siap. Namun masih ada harapan jika kita bisa mengambil pelajaran bangsa kita yang penuh semangant pantang menyerah dalam memajukan ilmu pengetahuan.

\section{Gambaran Umum Pesantren Hataska}

\section{Sejarah Berdiri}

Berdirinya Pondok Pesantren Hataska diawali dengan keinginan Bapak DR. H. Taher Ahmad (alm) dan istri beliau $\mathrm{Hj}$. Darnis Karim Taher (almh) sebelum meninggal pada tahun 1997 beliau sudah menanamkan niat untuk mendirikan lembaga pendidikan yang bernuansa Islami, karena sekolah menengah pertama (SMP) saat itu sudah cukup banyak, akan tetapi sedikit sekali yang bernuansa Islami atau memiliki pendidian pondok pesantren pada saat itu. Lembaga pondok pesantren juga sudah banyak tapi tidak menguasai atau mengedepankan pendidikan ilmu pengetahuan dan teknologi (IPTEK), melihat kondisi ril seperti ini terutama di kabupaten Kerinci, satu-satunya pondok pesantren yang memiliki kurikulum Departemen Pendidikan Dan Kebudayaan (DEPDIKBUD) saat itu.

Berdasarkan kondisi ini maka pada awal tahun 1998 DR. H. Taher Ahmad mengumpulkan para tokoh masyarakat, Tokoh Adat, Alim ulama, dan Tokoh pendidikan dirumahnya, maka pada pertemuan tersebut ternyata mendapat tanggapan positif dari berbagai element dan komponen masyarakat setelah mendengarkan gagasan

${ }^{24}$ Amin Haedari, Manajemen Pondok Pesantren (Jakarta: Diva Pustaka, 2004), h. 163 
dan cita-cita cemerlang beliau untuk mendirikan sebuah lembaga pendidikan yang mempunyai dua nuansa ilmu pengetahuan dan teknolgi dan ilmu pengetahuan agama, dengan latar belakang pemikiran beliau adalah: ${ }^{25}$

a. Sekolah umum begitu banyak, tapi belum tentu bermutu dan agamis serta mengedepnkan teknologi.

b. Sekolah madrasah dibawah naungan Departemen Agama (DEPAG) atau Kementerian Agama (KEMNAG) banyak, tapi hanya sedikit sekali pendalaman dibidang ilmu pengetahuan dan teknologi.

c. Untuk menjadi insanul kamil manusia yang sempurna apabila kedua hal tersebut diatas terhimpun pada diri seseorang yakni IMTAQ (iman dan taqwa) dan IPTEK. (ilmu pengetahuan dan teknologi)

Dengan dasar itulah lahir cita-cita beliau ingin menciptakan peserta didik yang berkualitas dengan tujuan sebagai berikut: ${ }^{26}$

a. Ingin mewujudkan peserta didik sebagai ulama yang intelektual dan berwawasan luas.

b. Menciptakan peserta didik sebagai cendikiawan yang agamawan.

c. Mampu untuk menjawab tantangan dan tuntutan zaman di era globalisasi dan informasi.

d. Meningkatkan mutu dan kwalitas umat Islam untuk meraih keunggulan dan kemenangan didunia melalui kifrah keilmuan dalam dunia pendidikan dan teknologi (IPTEK) mencapai keunggulan dan kebahagiaan akhirat melalui kifrah keimanan dan ketakwaan (IMTAQ)

e. Mempersiapkan kader pemimpin umat yang memiliki keterampilan ilmu pengetahuan dibidangnya serta kekuatan iman yang kuat lahir dan bathin serta menyadari fungsi hidupnya dimuka bumi sebagai khalifah (wakil) Allah.

f. Secara eksplisit menerapkan kader-kader ulama yang berkualitas, yang mampu menjadi panutan dan memberi pencerahan keagamaan ditengah masyarakat.

Maka 1998/1999, barulah sekolah ini sudah mulai secara perdana melaksanakan operasionalnya, dua tahun kemudian barulah resmi Pondok Pesantren Hataska mendapatkan persetujuan izin operasional pendirian Pondok Pesantren Hataska dari Departemen

25 Mainur Harjono, Ibid, 4

26 Mainur Harjono, Ibid., 5 
Agama kantor wilayah Provinsi Jambi dengan Nomor: w.e/6e/PP.00.7/331/2000 Dengan nomor statistik pondok: $512150105012^{27}$

\section{Visi dan Misi Sekolah}

visi $:^{28}$

Menciptakan kader-kader ilmuan Islami, dan kader-kader agamawan yang intelek,yang diharapkan mampu untuk menjawab dan memenuhi tuntutan pembangunan nasional yang dilandasi dengan pengetahuan umum dan teknologi (IPTEK) dan pengetahuan agama iman dan takwa (IMTAQ).

Misi:

1. Meningkatkan mutu dan kualitas umat Islam untuk meraih keunggulan dan kemenangan didunia melalui kiprah keilmuan dalam dunia pendidikan dan teknologi dan mencapai keunggulan dan kebahagian akhirat melalui kiprah keimanan dan ketakwaan (IMTAQ).

2. Mempersiapkan kader pemimpin umat yang memiliki keterampilan ilmu pengetahuan dibidangnya serta kekuatan iman yang mantap serta menyadari fungsi hidupnya dimuka bumi sebagai khalifah.

3. menghasilkan sumber daya manusia yang berpegang teguh kepada tiga prinsip: terpadu, bermutu, dan modern.

4. mencetak pribadi peserta didik sebagai pelaku pembangunan dalam berbagai bidang terutama dibidang sosial keagamaan yang sinkron dengan tuntutan zaman.

5. secara eksplisit menyiapkan kader-kader ulama yang berkualitas.

${ }^{27}$ Surta izin Operasional

${ }^{28}$ Profil Pondok Pesantren Hataska 


\section{Hasil Penelitian}

\section{Pelaksanaan Program Pemberdayaan}

1) Pelaksanaan program pemberdayaan spiritual

a. Pemberian materi

Kunjungan dan observasi yang penulis lakukan dan mengikuti kegiatan sholat berjamaah santri pada tanggal 18-23 Agustu 2016. ${ }^{29}$ Setiap selesai sholat dan dzikir berjamaah dan ditutup dengan do'a yang diimami oleh salah satu santri kemudian dilanjutkan dengan sholat sunah rawatib, setelah itu pimpinan pondok memberikan pengarahan secara umum tentang pentingnya sholat berjamaah diawal waktu dan menyampaikan agar santri tidak ada yang terlambat kemasjid, kemudian mengingatkan kepada pembina asrama agar selalu mengingatkan santri menjelang waktu sholat agar tidak ada santri yang terlambat kemasjid. Hal ini selalu disampaikan oleh pimpinan setiap selesai melaksanakan sholat berjamaah.

a. Fiqih Ibadah

Menurut Kepala Asrama Pondok Pesantren Hataska ${ }^{30}$ belajar fikih ibadah di Pondok Pesantren Hataska merupakan salah satu mata pelajaran pokok yang diterapkan di Pondok Pesantren Hataska, karena dalam materinya membahas tentang dasar-dasar dalam pelaksanaan ibadah.

Adapun silabus atau materi pokok mata pelajaran fikih ibadah di Pondok Pesantren Hataskan adalah: ${ }^{31}$ a). Praktek memasang kain sarung/ pakayan muslim dan muslimah. b). Bab Taharoh. c). Bab Sholat. d). Bab Puasa. e). Bab Dzakat. f). Bab Haji dan Umbroh.

Berdasarkan pengamatan penulis bahwa pada kegiatan inti, kiyai atau ustadz sangat menguasai materi pembelajaran, metode yang digunakan ceramah dan tanya jawab dengan sedikit metode hafalan, demonstrasi, latihan, penugasan, dan praktek.

b. Seni baca Al-Qur'an

${ }^{29}$ Hasil observasi penulis pada tanggal 18 - 23 Agustus 2016

${ }^{30}$ Syafrial Arif, wawancara pribadi (kepala asrama pondo Pesantren Hataska), Selasa 16 Agustus 2016

${ }^{31}$ Silabus mata pelajaran Fiqih Ibadah santri Pondok Pesantren Hataska 
Berdasarkan hasil observasi penulis pada tangga 20 Juli $2016^{32}$ pelaksanaan belajar Seni Baca Qur'an pada santri Pondok Pesantren Hataska terlihat mereka hampair 50\% dari peserta memiliki suara yang mendukung untuk dalam belajar irama Al-quran namun terlihat mereka sangat awam terhadap irama yang populer digunakan dalam Musabaqoh Tilawatil Quran (MTQ), mereka menggunakan irama yang mereka buat sendiri, hal ini terlihat menjelang pembimbingnya datang sebagian besar santri sangat latihan membaca $\mathrm{Al}$-quran dengan iramanya masing-masing.

c. Dakwah

Kunjungan penulis pada tanggal 01-07 Agustus 2016 33 penulis mengikuti santri belajar dakwah bersama pembinanya, pada pertemuan ini santri diwajibkan untuk menampilkan hafalan konsep dakwah satu-persatu di hadapan kelasnya dihadapan temantemannya.

Pada kunjungan peneliti tanggal 14-20 Agustus 2016 ${ }^{34}$ santri yaitu santri baru mendapatkan jadwal dakwah di masjid pondok pesantren, artinya dihadapan seluruh santri dan dihadapan pembina Pondok Pesantren Hataska sesudah sholat subuh.

2) Pelatihan

a. Sholat Berjamaah

Kunjungan penulis pada minggu berikutnya pada tanggal 01-07 Agustus 2016 ${ }^{35}$ penulis melakukan pengamatan bahwa pelaksanaan sholat berjamaah santri Pondok Pesantren Hataska sudah mulai teratur, hanya tinggal dua atau tiga orang yang terlambat dalam sholat berjamaah lima waktu dan beberapa orang yang putri yang berhalangan sholat, dalam sholat berjamaah mereka sudah mulai tenang dan hanya ada satu dua orang yang terdengar batuk-batuk sambil menahan tertawa, dan dalam zikir berjamaah setelah sholat berjamaah banyak yang mengikuti walaupun mereka belum hafal semuanya, namun bacaan zikir berjamaah sudah terdengar semakin ramai, dan terutama bagi santriwan agar semuanya mengikuti bacaan dzikir walupun sebagian besar santri baru belum hafal.

\footnotetext{
${ }^{32}$ Hasil observasi penulis pada tanggal 18-23 Juli 2016

${ }^{33}$ Hasil observasi penulis pada tanggal 01-07 Agustus 2016

${ }^{34}$ Hasil observasi penulis pada tanggal 14-20 Agustus 2016

${ }^{35}$ Hasil observasi penulis pada tanggal 01-07 Agustus 2016
} 
Kunjungan penulis pada minggu berikutnya yaitu pada tanggal 14-20 Agustus 201636 berdasarkan pengamatan penulis bahwa pelaksanaan sholat berjamaah di Pondok Pesantren Hataska semakin baik, terlihat hanya tinggal satu dua santri saja yang terlambat namun tetap sholat berjamaah dan kemudian mendapat sangsi dari pembina asrama, dan ada beberapa orang yang putri berhalangan sholat. Dalam pelaksanaan sholat berjamaah juga sudah mulai teratur, seperti terlihat diwaktu mengatur shaf, sebelum imam takbiratur ikhram semuaya sudah tenang dan shaf sudah rapi, semua jamaah tenang dan tidak terdengar lagi santri yang tertawa dan batuk-batuk berlebihan seperti sholat-sholat sebelumnya.

b. Fikih Ibadah

Observasi penulis pada tanggal 18-23 Juli $201^{37}$ santri Pondok Pesantren Hataska belum begitu memahami cara berpakayan seorang santri, terlihat ada sebagian santriwan yang memakai celana pendek diluar asrama, walaupun sudah diberi tau oleh pembina dan kakak senior, cara mereka memakai kain sarung yang terlihat belum pas, yang santriwati banyak yang belum bisa memasang jilbab, terliha ketika mereka keluar asrama yang penting tertutup kepalanaya. Dalam berwuduk banyak yang belum tau cara berwuduk yang benar dan bahkan ada yang tidak berwuduk.

Pada tanggal 21-23 Juli 2016 santri mengikuti kegiatan belajar Fiqih Ibadah dengan mempraktekkan satu persatu cara memasang sarung dan dianjutkan dengan praktek berwuduk dan praktek sholat bersama pembina masing-masing dan di kelas masing-masing, sedangkan yang putri belajar di dalam asrama dan di dalam masjid bersama ustadzahnya masing-masing belajar memasang jilbab, mukena, dan pakayan muslimah yang benar.

c. Seni Baca Al-quran

Kunjungan penulis pada 03 Agustus 2016 ${ }^{38}$ terlihat santri Pondok Pesantren Hataska mengikuti secara bersama-sama membaca ayat al-Quran setelah pembimbing membacakan sepotong ayat dengan iramanya, hal ini dilakukan dengan berulang-ulang agar santri dapat memahami dan mengingat irama yang digunakan.

\footnotetext{
${ }^{36}$ Hasil observasi penulis pada tanggal 14-20 Agustus 2016

${ }^{37}$ Hasil observasi penulis pada 18-23 Juli 2016

${ }^{38} \mathrm{Hasil}$ observasi penulis pada tanggal 03 Agustus 2016
} 
d. Dakwah

Kunjungan penulis pada tanggal 01-07 Agustus 201639 penulis mengikuti santri belajar dakwah bersama pembinanya, pada pertemuan ini santri diwajibkan untuk menampilkan hafalan konsep dakwah satu-persatu di hadapan kelasnya dihadapan temantemannya. Dalam pertemuan ini penulis melakukan pengamatan bahwa terlihat semua santri dapat menghafalkan dan menampilan konsep ceramah untuk penampilan selam 10 menit dihadapan pembina dan teman-teman sekelasny. Pada kunjungan peneliti tanggal 14-20 Agustus 2016 ${ }^{40}$ santri yaitu santri baru mendapatkan jadwal dakwah di masjid pondok pesantren, artinya dihadapan seluruh santri dan dihadapan pembina Pondok Pesantren Hataska sesudah sholat subuh.

Berdasarkan kunjungan penulis ini terlihat santri memang sudah berani tampil dihadapan teman-temannya sekelas, namun ketika tampil di dalam masjid di hadapan seluruh santri dan pembina mereka belum berani untuk tampil sendiri melainkan ia mengajak satu orang temannya untuk menemani ia berdiri di depan teman-temannya. Walaupun demikian menurut penulis ini merupakan perkembangan yang cukup baik menjadi langkah awal mereka untuk terbiasa tampil didepan orang banyak.

2. Pelaksanaan Program Pemberdayaan Life Skill (keterampilan hidup)

1). Pemberina materi

a. Teknik Sepeda Motor (TSM), dan Teknologi Informasi dan Komunikasi (TIK)

Observasi penulis terhadap pelatihan teknik sepeda motor dan teknologi informasi komunikasi terhadap santri Pondok Pesantren Hataska pada tanggal 24 Juli $2016^{41}$ terlihat santri mendengarkan dan menulis materi yang diberikan pembimbing, tentang pengenalan terhadap komponenkomponen sepeda motor dan pengenalan terhadap perangkat komputer, semua santri tenang dan sesekali menulis yang dianggap perlu tentang apa yang disampaikan oleh pembimbing.

${ }^{39}$ Hasil observasi penulis pada tanggal 01-07 Agustus 2016

${ }^{40} \mathrm{Hasil}$ observasi penulis pada tanggal 14-20 Agustus 2016

${ }^{41}$ Hasil observasi penulis pada tanggal 24 Juli 2016 
b. Kepramukaan

Observasi yang penulis lakukan pada tanggal 22 Juli $2016^{42}$ semua santri diwajibkan untuk mengikuti kegiatan pramuka, pada kegiatan ini terlihat santri mengikuti upacara pembukaan dan mendengar pengarahan dari kepala sekolah sebagai pembina upacara sekaligus membuka kegiatan pramuka, dilanjutkan dengan pengarahan dari pembina pramuka serta memandu latihan bari berbaris dan latihan upacara pembukaan sebagai petugasnya santri baru.

Kunjungan penulis Pada tanggal 29 Juli 2016, penulis melakukn observasi, ${ }^{43}$ terlihat santri baru sebagai petugas pelaksana upacara pembukaan, dialanjutka dengan pengarahan pembina pramuka dan pembagian regu, setelah pembagian regu mereka dikumpulkan perregu masing-masing dan dibantu oleh kakak penegak untuk memberi materi tentang kepramukaan, memasang tenda, membuat tandu, membuat tiang bendera, membuat tempat masak.

c. Seni Bela Diri

Observasi penulis pada tangga 30 Juli 2016 ${ }^{44}$ santri mendengarkan pengarahan serta penjelasan dari pelatih mengenai tujuan kegiatan latihan bela diri, dan menjelaskan tentang aliran seni bela diri aliran persaudaraan setia hati terate (PSHT) serta memotifasi santri untuk mngikuti latihan.

d. Bahasa Arab dan Bahasa Inggris

Obserfasi yang penulis lakukan pada tanggal 18-23 Juli $2016^{45}$ bahwa pelaksanaan pembelajaran bahasa Arab dan bahasa Inggris. Dalam pelaksanaan bembelajaran bahasa Arab dan bahasa Inggris pada tahap awalnya diutamakan pada pemberian dan mengahafal kosakata yang sering digunakan setiap hari, dengan memberikan 15-20 kosakata kemudia disetorkan kepada pembina masing-masing, hal ini agar santri dapat mempraktek kosakata yang sudah dihafal dalam kegiatan sehari-hari.

\footnotetext{
${ }^{42}$ Hasil observasi penulis pada tanggal 22 Juli 2016

${ }^{43}$ Hasil observasi penulis pada 29 Juli 2016

${ }^{44}$ Hail observasi penulis pada tanggal 30 Juli 2016

${ }^{45}$ Hasil observasi penulis pada tanggal 18-23 Juli 216
} 
Observasi penulis pada 01-07 Agustus 201646 pada santri baru, yang belajar bahasa Arab dan bahasa Inggris msih menghafal kosakata yang diberikan oleh pembina asrama sebanyak 15-20 kosakata kemudian disetorkan kepada pembina masing-masing.

e. Belajar khaligrafi

Berdasrkan jadwal yang sudah ditentukan ${ }^{47}$ bahwa Pondok Pesantren Hataska menerapkan pelajaran khaligrafi pada sore hari, yaitu pada jam 13. 40 sampai dengan jam 15.00, pelajaran khaligrafi ini dilaksanakan hanya tiga hari saja, yaitu pada hari senin, hari selasa dan hari rabu. Pengamatan dan observasi penulis pada tanggal 18-23 Juli $2016^{48}$ kegiatan belajar kahligrafi pada santri kelas VII Pondok Pesantren Hataska mempersiapkan bahan seperti pensil besar (sering disebut dengan pensil tukang) dan batang pakis yang sudah kering (sering disebut dengan batang pakis rimba) kemudian kertas karton dan tinta, pembina memberikan materi tentang pengenalan terhadap haligrafi dan menjelaskan kegunaan alatalat yang sidah disiapkan oleh santri masing-masing.

2). Pelatihan

a. Teknik sepeda motor dan teknologi informasi komunikasi

Kunjungan penulis pada 21 Agustus $2016^{49}$ pada kegiatan belajar teknik sepeda motor dan kegiatan belajar teknologi informasi dan komunikasi, untuk santri yang belajar teknik sepeda motor ada 7 orang santri yang dikirim kebengkel utama untuk praktek langsung memberi pelayanan kemasyarakat, yang terletak di depan sekolah dan masih milik sekolah yang membuka pelayanan langsung kemasyarakat, sebagin santri yang lain masih praktek pada bengkel didalam lingkungan sekolah untuk mengulangi materi-materi yang sudah pernah diajarkan agar lebih mahir.

Santri yang belajar teknologi informasi dan komunikasi (TIK) pada labor komputer terlihat pembimbing sedang memberi materi tentang jarigan internet, dan tentang email

\footnotetext{
${ }^{46}$ Hasil observasi penulis pada tanggal 01-07 Agustus 2017

${ }^{47} \mathrm{Jadwal}$ kegiatan belajar khaligrafi santri Pondok Pesantren Hataska

${ }^{48}$ Hasil observasi penulis pada tanggal 18-23 Agustus 2016

${ }^{49}$ Hasil observasi penulis pada tanggal 21 Agustus 2016
} 
kemudian semua santri membuat akun email mereka masingmasing. Jadi pemahaman santri tentang teknik sepeda motor dan teknologi informasi dan komunikasi semakin baik terlihat dari kegiatan praktek santri dan terlihat pada peningkatan materi yang diberikan oleh pembimbing.

b. Kepramukaan

Pada tanggal 14 Agustus 2016 jam 09. ${ }^{00}$ pagi santri kembali dikumpulkan di lapangan untuk persiapan berangkat tadabbur alam, mereka diberangkatkan perregu dengan rentan waktu sepuluh menit dan siap untuk menjawab pertanyaan serta perintah di setiap pos sepanjang perjalanan yang sudah disiapkan, pada jam $16 .{ }^{00}$ semua regu telah sampai ditempat perkemahan, selama dalam perjalanan terlihat kekompakan anggota kelompok, ketika ada temannya yang sakit mereka siap memberi pertolongan dan membawanya pakai tandu sampai ketempat perkemahan dan bahkan sampai pulang kembali, terlihat santri mengikuti kegiatan ini dengan semangat dan gembira, disiplin yang tinggi dan persaudaraan yang baik. Pada tanggal 16 Agustus 2016 kemudian santri sampai di sekolah kembali dan kemudan diperintahkan untuk istirahat di asrama masing-asing.

c. Seni bela diri

Menurut informasi yang penulis dapatkan bahwa ${ }^{50}$ prestasi yang pernah diukir oleh pasukan inti ini baik dalam satuan tingkat desa, kecamatan, kabupaten bahkan provinsipun seni bela diri persaudaraan setia hati terate (PSHT) Pondok Pesantren Hataska telah menunjukkan keunggulannya, yaitu memperoleh juara 11 putra dan juara 111 putri tinggakat provinsi Jambi cabang laga dan memperoleh juara lll pada cabang tungga. Dengan berkembangnya minat santri dalam mengikuti kegiatan bela diri ini dapat memacu untuk tumbuhnya generasi Islami yang terbaik bukan hanya dari sisi rohani saja melainkan juga dari sisi jasmani, karena di dalam badan yang sehat terdapat jiwa yang kuat.

${ }^{50} \mathrm{Abu}$ Bakar, wawancara pribadi penulis (pimpinan pondok pesantren Hataska). Minggu 31 Juli 2016 
d. Bahasa Arab dan bahasa Inggris

Kunjungan penulis dan melakukan observasi pada tanggal 22-27 Agustus $^{51}$ santri kelas VII mulai belajar kaidah-kaidah dalam bahasa Arab dan bahasa Inggris, dan penulis melihat pada santri kelas VII sudah mulai menggunakan bahasa Arab dan bahasa Inggris dalam percakapan sehari-hari walaupun masih dicampur dengan bahasa Indonesia.

e. Khaligrafi

Kunjungan observasi penulis pada tanggal 22-27 Agustus 201652 santri kelas VII membuat kahligrafi pada papan triplek sedangkan kelas VII, dan satu papan dikerjakan satu orang bagi kelas VIII dan kelas IX.

\section{Kesimpulan}

1. Program pemberdayaan Pondok Pesantren Hataska kabupaten KerinciJambi ada dua bentuk yaitu program pemberdayaan spiritual dan pemberdayaan life skill. Pemberdayaan spiritual berupa pemberdayaan dalam sholat berjamaah, belajar fiqih ibadah, belajar seni baca Al-quran, dan belajar dakwah. Pemberdayaan life skill berupa pemberdayaan belajar teknik sepeda motor (TSM), belajar teknologi informasi dan informasi (TIK), kegiatan kepramukaan, belajar seni bela diri, belajar bahasa Arab dan bahasa Inggris, dan belajar khaligrafi.

2. Pelaksanaan program pemberdayaan Pondok Pesantren Hataska kabupaten Kerinci-Jambi dilaksanakan dengan tiga tahapan pelaksanaan, yaitu tahapan pemberian materi, tahapan pelatihan, dan tahapan pelaksanaan

\section{Saran}

1. Program pemberdayaan santri Pondok pesantren Hataska Semurup kabupaten Kerinci-Jambi, agar dapat dikembangkan pada bidang-bidang yang lain seperti pemberdayaan dibidang pertnian dan peternakan, pengembangan dibidang usaha seperti yang dilakukan oleh Pondok Pesantren Daruttaubid yang dipimpin oleh Abdulla gimnastiar dan pesantren yang lain mengingat lokasi pondok pesantren masih banyak

${ }^{51}$ Hasil observasi penulis pada tanggal 22-27 Agustus 2016

${ }^{52}$ Hasil observasi penulis pada tanggal 22-27 Agustus 2016 
yang kosong, serta pembelajaran kitab kuning sebagai ciri khas utama sebuah lembaga pondok pesantren

2. Untuk pemerintah kabupaten dan provinsi serta masyarakat sekitar agar dapat memberi perhatian yang lebih kepada pengembangan Pondok Pesantren Hataska, dapat dilakukan dengan sumbangan materil maupun imateril.

3. Pengembangan terhadap santri secara keilmuan wajib untuk diketahui seluruh elemen, termasuk pondok pesantren. Demikian juga pejabat daerah, lembaga sawadaya dan instansi swasta serta pengusaha yang mau dan berkompeten dalam bidang masing-masing agar memiliki kecakapan dalam melakukan kegiatan-kegiatan yang berkaitan dengan pengembangan masyarakat.

\section{Daftar Kepustakaan}

Daulay, Putra, Haidar, Pendidikan islam: dalam sistem pndidikan nasional di Indonesia, (Jakarta: Kencana 2004).

Dhofier, Zamakhsyari, Tradisi Pesantren: Studi tentang Pandangan Kyai (Cet. VII; Jakarta: LP3ES,1997)

Mujib, A, et. al., Intelektualisme Pesantren: Potret Tokoh dan Cakrawala Pemikiran di EraPerkembangan Pesantren (Cet. III; Jakarta: Diva Pustaka, 2006)

Departemen Agama Repoblik Indonesia, Pedoman Pembinaan Pondok Pesantren, ( Jakarta; Ditjen Bimbingan Islam, 1985).

Ziemek, Manfred , Pesantren Dalam Perubahan Sosial (Cet. I; Jakarta: P3M, 1986).

Johns, A.H., Rom Coastal Settlement To Islamic School And Citi: Islamization in Sumatra, The Malay Paninsula And Java, Dalam J. Fox (ed), Indonesia: The Making of a Culture (Camberra: RS. P.S., 1980).

Big, C.C., "Indonesia" dalam H.A.R. Gibb (ed). Whiter Islam ; A Survey of ModerenMovement in The Moslem World, (London; 1932).

Wahied, Marzuki, (dkk), Pesantren Masa Depan Wacana Pemberdayaan Dan Transpormasi Pesantren (Bandug: Pustaka Hidayah, 2000)

Azwar, Welhendri, Sosiologi Dakwah, (Padang: Imam Bonjol Press. 2014).

Muslim, Aziz, Metodologi Pengembangan Masyarakat, (Yogyakarta: Teras, 2009). 
Setiana L, Teknik Penyuluban dan Pemberdayaan Masyarakat, (Bogor: Bhalia Indonesia, 2005).

Suyono, Pedoman Pelaksanan KKN Pos Pemberdayaan Keluarga (Posdaya), (Jakarta: Citra Kharisma Bunda, 2009).

Mujib, A, et. al., Intelektualisme Pesantren: Potret Tokoh dan Cakrawala Pemikiran di EraPerkembangan Pesantren (Cet. III; Jakarta: Diva Pustaka, 2006)

Haedari, Amin, et al., Masa Depan Pesantren Dalam Tantangan Modernitas dan Komplesitas Global, (Jakarta: IRD Perss, 2004).

Aly, Abdullah, Pendidikan Multikultural di Pesantren Telaah Terhadap Kurikulm Pesntren Moderen Islam Asslalam Surakarta, (Yogyakarta: Pustaka Pelajar, 2011).

Haedari, Amin, Manajemen Pondok Pesantren, (Jakarta: Diva Pustaka, 2004). 